\title{
Model Green SCOR Untuk Pengukuran Kinerja Green Supply Chain Management (GSCM) Industri Kelapa Sawit di Indonesia
}

\author{
Rangga Primadasa*, Akh Sokhibi \\ Teknik Industri, Fakultas Teknik, Universitas Muria Kudus, Kudus \\ *Penulis korespondensi: rangga.primadasa@umk.ac.id
}

Histori artikel: diserahkan 25 Januari 2020, direviu 28 Januari 2020, direvisi 18Februari 2020

\begin{abstract}
This paper aims to create Key Performance Indicators (KPIs) to evaluate green supply chain management (GSCM) in Indonesia's palm oil industry. Green supply chain management (GSCM) is a method to integrate environmental aspectsi into their supply chain. The method in creating KPIs using The Green SCOR Model as a basis to develop green objectives and all ofthe indicators. There are 23 KPIs from 9 green target for GSCM of the palm oil industry in Indonesia. To ensure KPIs more precise, then the impotance level of KPIs was measured using the analaytic hierarchy process (AHP). According to the experts in palm oil industries there is managing plantations and palm oil mills are using ISPO and RSPO certification as the dominant green objectives (29.7\%), followed by minimizing and tackle emission from global warming gas $(15,9 \%)$ and manage waste $(11,8 \%)$.
\end{abstract}

Keywords: Green Supply Chain Management (GSCM), Key Performance Indicators, Green Scor, Palm Oil Industry

DOI: $10.18196 /$ jqt.010209

Web: http://journal.umy.ac.id/index.php/qt

\section{PENDAHULUAN}

Industri kelapa sawit merupakan industri yang sangat penting bagi Indonesia, ini bisa kita lihat dari data bahwa luas perkebunan kelapa sawit tahun 2017 11,9 juta hektar (ha), dimana 42 persen diantaranya adalah kebun rakyat. Sementara itu produksi CPO ( Crude Palm Oil ) tahun 2017 mencapai 38 juta ton diaman 31 juta ton diekspor ke lebih dari 50 Negara (https://economy.okezone.com/read/2018/03/1

5/...). Industri kelapa sawit yang berada di 190 kabupaten di Indonesia memiliki peran yang sangat penting dalam membangun perekonomian daerah, menciptakan pusatpusat pertumbuhan ekonomi baru, selain itu juga mengurangi angka kemiskinan (https://gapki.id/news/...).

Aspek lingkungan hidup sangat penting diperhatikan dalam operasional industri kelapa sawit (https://sawitindonesia.com/...). Industri kelapa sawit dikaitkan dengan hilangnya keanekaragaman hayati, polusi,kebakaran hutan dan peningkatan emisi gas rumah kaca.
Kedua, ada tendensi bahwa saat ini orang cenderung untuk membelanjakan uang pada produk yang memiliki dampak baik pada lingkungan hidup dan orang juga cenderung menunjukkan minat pada produk yang berasal dari perusahaan yang punya reputasi baik pada lingkungan hidup (Kusrini \& Primadasa, 2017).

Aspek lingkungan saat ini sudah menjadi keharusan untuk diaplikasikan di dalam supply chain sebuah perusahaan. Aspek lingkungan dalam prakteknya cenderung tidak terintegrasi di dalam supply chain atau rantai pasok dari perusahaan, sehingga berjalan kurang efektif. Salah satu cara mengintegrasikan aspek lingkungan ini kedalam supply chain adalah green supply chain management (GSCM).

Aspek utama dalam green supply chain adalah untuk meningkatkan performa dari dua aspek yaitu ekonomi dan lingkungan (Zhu et al., 2004). Penerapan GSCM dapat mengurangi pencemaran lingkungan dan mengefisienkan rantai pasok perusahaan (Natalia \& Astuario, 2015). GSCM memiliki tujuan mengelininasi 
waste di dalam supply chain atau rantai pasok meliputi ebergi, emisi, gas kimia berbahaya, serta limbah (Fortuna et al., 2014). Model SCOR adalah sebuah alat untuk mendiagnosa supply chain management (SCM) yang memungkinkan penggunanya untuk memamahi semua proses di dalam

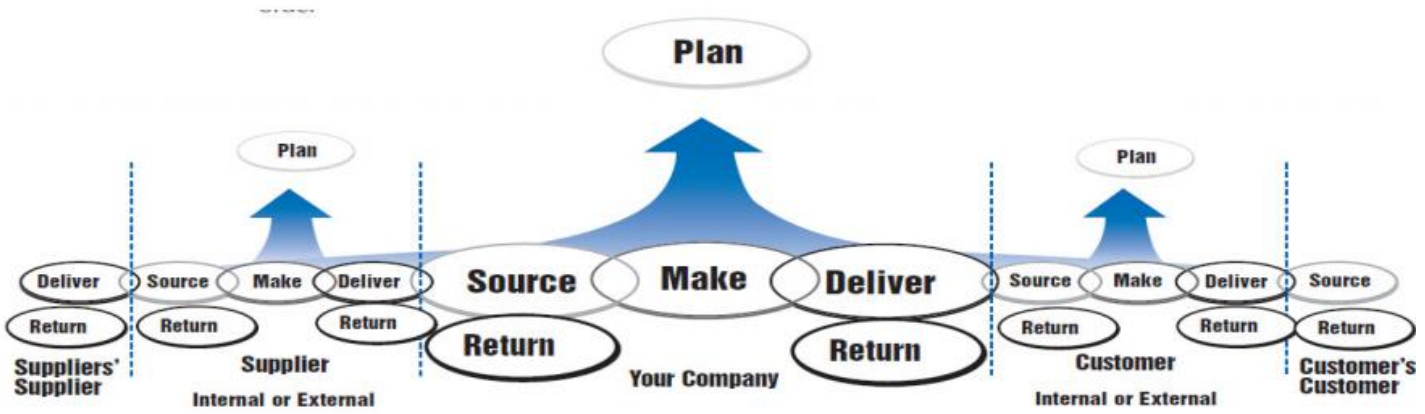

GAMBAR 1. Model Green SCOR

sebuah organisasi bisnis dan juga untuk memahami fitur yang utama untuk memenuhi kepuasan konsumen. Model SCOR diorganisasi kedalam 5 proses menejemen meliputi plan, source, make, deliver, dan return, yang kemudian dibagi kedalam bagianbagian meliputi process categories, elements, tasks dan activities. Sementara itu Green SCOR adalah modifikasi dari model SCOR dimana aspek lingkungan diintegrasikan ke dalam proses SCM (Ntabe et al., 2015). Penelitian ini memiliki tujuan mengukur kinerja GSCM dari sebuah industri kelapa sawit menggunakan metode Green SCOR.

\section{DASAR TEORI}

\section{GSCM (Green Supply Chain Management)}

Konsep supply chain management (SCM) telah berkembang dari integrasi internal dan eksternal menuju sinergi antar fungsional, koordinasi dan integrase antar organisasi (Min $\&$ Zhou, 2002). GSCM memiliki tujuan untuk membatasi waste di dalam sistem industri dalam rangka penghematan energi dan mencegah limbah berbahaya masuk ke lingkungan (Torres et al., 2004). GSCM adalah gabungan dari green purchasing, green manufacturing, green packing, green distribution and marketing. GSCM dimaksudkan untuk meminilaisir berbagai jenis limbah seperti kimia, energi, emisi, padat (Olugu et al., 2010).

\section{Model SCOR}

Supply chain telah berevolusi ke dalam rantai yang efisien dengan menggunakan metodemetode terbaru. Guna meningkatkan pelayanan sebuah rantai pasok membutuhkan model standar untuk mengukur operasional dan performa mereka. Model SCOR dikembangkan oleh Supply Chain Council (SCC), untuk mengukur performa dari rantai pasok. Model SCOR menyediakan standar terminology yang dapat digunakan dalam menentukan, mengatur dan mengimplementasikan proses supply chain. Gambar 1 menunjukkan model SCOR yang memiliki beberapa proses antara lain: plan, source, make, deliver dan return (Delipinar et al., 2016).

Plan: meliputi menganalisa informasi dan peramalan tren pasar dari produk barang dan jasa. Departemen pemasaran dan keuangan mengaplikasikan proses perencanaan tiap bulan dan melaporkan tiap tahun. Source: meliputi sistem pengadaaan seperti pencarian, negosiasi dan evaluasi supplier untuk penyeleksian supplier baru. Make: meliputi proses pembuatan produk atau pengolahan dalam industri proses dalam waktu tertentu juga termasuk jumlah batch produksi. Deliver: meliputi proses yang mana sebuah produk jadi dan servis dapat memenuhi permintaan yang direncanakan atau perminataan actual. Return: meliputi proses pengembalian atau penerimaan produk (Delipinar et al., 2016). Gambar 1 menunjukkan Model Green SCOR. 


\section{Model Green SCOR}

Green SCOR adalah modifikasi dari model SCOR dimana aspek lingkungan dintegrasikan ke dalam rantai pasok barang atau jasa [8]. Model Green SCOR adalah pengembangan dari model SCOR, sehingga juga memiliki 5 komponen utama yaitu Plan, Source, Make, Deliver, dan Return. Setiap prosesnya memilik sub proses untuk mengurangi dampak terhadap lingkungan (Natalia \& Astuario, 2016). Plan dalam industri kelapa sawit merupakan tahapan awal dalam keseluruhan rantai pasokan, dimana aktivitasnya meliputi merencanakan TBS olah baik tahunan, bulanan, mingguan, atau harian. Dalam aktivitas plan juga direncanakan bagaimana dalam setiap aktivitas di dalam supply chain tidak berdampak buruk terhadapat lingkungan, merencanakan bagaimana memindahkan dan menyimpan material berbahaya yang digunakan dalam operasional, merencanakan pengolahan limbah dan waste. Source process pada industri kelapa sawit meliputi proses pemesanan pengiriman TBS (Tandan Buah Segar) dari kebun baik dari kebun sendiri, kebun tetangga, maupun kebun kemitraan, pemilihan juga didasarkan pada reputasi kebun tersebut dalam memperhatikan aspek lingkungan. Source process juga meliputi pengiriman TBS ke PPKS ( Pabrik Pengolahan Kelapa Sawit), memperhatikan emisi yang dikeluarkan dalam pengiriman TBS. Make process pada industri kelapa sawit bukan proses membuat tetapi memproses dari bahan baku TBS menjadi CPO (Crude Palm Oil). Make process juga memperhatikan bagaimana aktivitas di setiap stasiun kerja di PPKS, waste-nya minim, serta bagaimana waste tersebut di manage. Make process juga memperhatikan bagaimana emisi yang dihasilkan dimanage, energi yang digunakan juga minim. Delivery process dalam industri kelapa sawit berkaitan dengan dengan upaya melakukan kontrak penjualan dengan konsumen seperti industri minyak goreng, biofuel, dan industri lain yang menggunakan CPO sebagai bahan baku. Delivery process di sini berkaitan dengan bagian sales, dimana informasi stok CPO yang dihasilkan bisa sebagai acuan informasi yang diberikan kepada konsumen. Delivery process juga berkaitan dengan pemilihan transportasi untuk pengiriman CPO kepada konsumen. Penting diperhatikan adalah pengiriman sesuai dengan jadwal dan tentu emisi yang dikelurkan
minim.Return berkaitan dengan proses pengembalian produk ke perusahaan dikarenakan oleh berbagai alasan.

\section{METODE PENELITIAN}

Penelitian ini memiliki beberapa tahapan, yang pertama adalah melakukan studi literatur yang berkaitan dengan metode Green SCOR, yang kedua adalah studi lapangan untuk mengumpulkan data. Studi lapangan dilakukan di sebuah perusahaan pengolahan kelapa sawit (PPKS). Data yang dikumpulkan meliputi : supply chain PPKS, identifikasi kebutuhan stakeholder berkaitan dengan lingkungan di dalam supply chain, identifikasi green requirements dan green objectives dari setiap stakeholder. Hasil dari proses study literature dan studi lapangan akan digunakan untuk merancang KPI (Key Performance Indicators) GSCM industri kelapa sawit.

Perancangan KPI untuk pengukuran GSCM industri sawit dilakukan dalam beberapa langkah. Pertama dilakukan identifikasi model rantai pasok industri kelapa sawit. Kedua melakukan pemetaan rantai pasok menggunakan model Green SCOR. Pemodelan ini lebih objective untuk mengkorelasikan kebutuhan stakeholder mengenai aspek lingkungan dengan atribut kinerja Green SCOR. Setelah green objectives untuk setiap stakeholder telah diketahui maka dibuatlah key performances indicator-nya.

Setelah didapatkan KPI GSCM untuk industri kelapa sawit maka tahap selanjutnya adalah pembobotan setiap KPI menggunakan metode AHP (Analytical Hierarchy Process).

\section{HASIL DAN PEMBAHASAN}

\section{Identifikasi Requirements Stakeholder}

Pada tahapan ini kita melakukan identifikasi requirements dari setiap stakeholder di dalam rantai pasok. requirement di sini masih bersifat umum, namun requirement yang berkenaan dengan lingkungan hidup (green requirements) juga diidentifikasi. dari stakeholder di dalam supply chain industri kelapa sawit mulai dari kebun, bagian transportasi, hingga proses pengolahan dan pengiriman $\mathrm{CPO}$ ditabulasi pada Tabel 1. 
TABEL 1. Kebutuhan Setiap Stakeholder Pada Rantai Pasok Industri Sawit

\begin{tabular}{|c|c|}
\hline Stakeholder & Requirements \\
\hline $\begin{array}{l}\text { Supplier Tandan } \\
\text { Buah Segar Sawit } \\
\text { (Kebun Sendiri, } \\
\text { Kebun Kemitraan, } \\
\text { dll. ) }\end{array}$ & $\begin{array}{ll}\text { - } & \text { Harga perkilo TBS yang } \\
\text { dibeli PPKS tinggi } \\
\text { - } \\
\text { Pengelolahan Kebun } \\
\text { sesuai dengan ketentuan } \\
\text { ISPO dan RSPO } \\
\text { - TBS yang dikirim ke } \\
\text { PPKS bersih dari sampah } \\
\text { - Pengolahan perkebunan } \\
\text { dengan emisi rendah }\end{array}$ \\
\hline $\begin{array}{l}\text { Bagian penerimaan } \\
\text { TBS (di jembatan } \\
\text { timbang PPKS dan } \\
\text { bagian grading) }\end{array}$ & 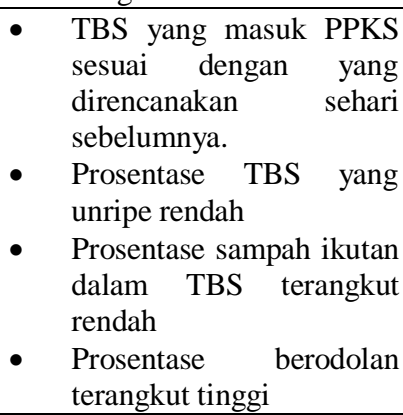 \\
\hline $\begin{array}{l}\text { Bagian Transportasi } \\
\text { (Pengiriman Tandan } \\
\text { Buah Segar Sawit Ke } \\
\text { PPKS) }\end{array}$ & 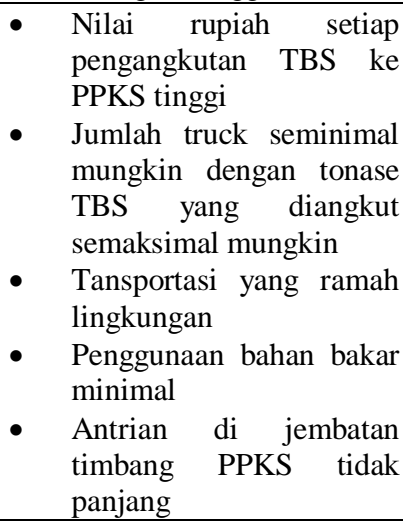 \\
\hline $\begin{array}{l}\text { Bagian Pengolahan } \\
\text { (Produksi CPO) }\end{array}$ & 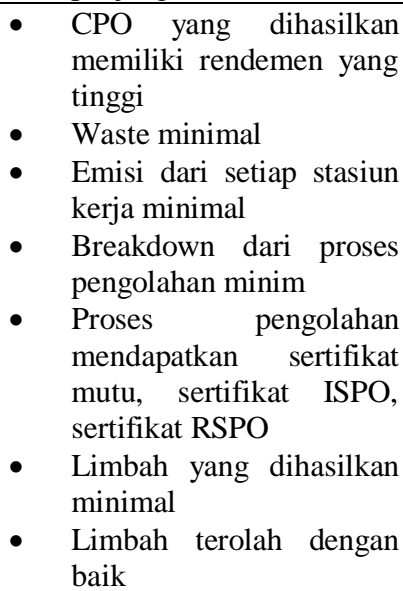 \\
\hline $\begin{array}{l}\text { Bagian Penjualan } \\
\text { dan Pemasaran }\end{array}$ & $\begin{array}{llr}- & \text { Harga jual CPO tinggi } \\
\text { - } & \text { Pemenuhan persyaratan } \\
\text { legalitas dan ramah } \\
\text { lingkungan r untuk } \\
\text { mengurangi komplain } \\
\text { dari customer } \\
\text { Kapal tongkang yang } \\
\text { digunakan } \\
\text { pengiriman CPO sesuai } \\
\text { kapasitasnya } \\
\end{array}$ \\
\hline
\end{tabular}

\section{Pemetaan Rantai Pasok Menggunakan}

\section{Pola Green SCOR}

Gambaran rantai pasokan industri sawit disesuaikan dengan Green SCOR model ditampilkan pada Gambar 2.

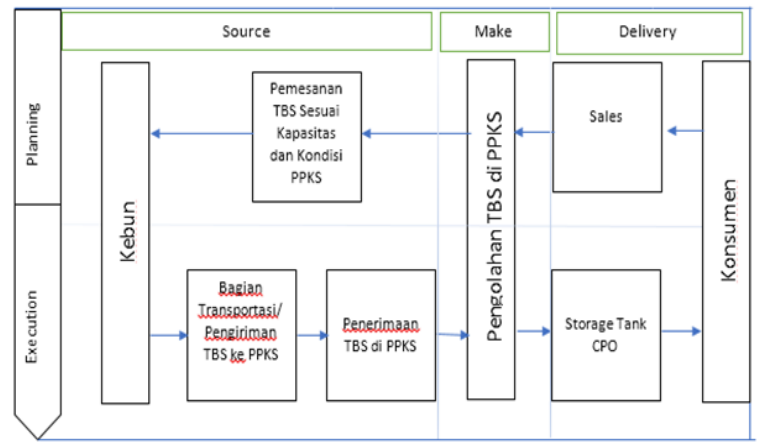

GAMBAR 2. Pola Aliran Rantai Pasok Industri Sawit

\section{Identifikasi Green Objectives}

Green objectives merupakan tujuan dari setiap stakeholder di rantai pasok berkenaan dengan pengurangan dampak terhadap lingkungan. Green objectives dari industry sawit yang telah tersusun ditamplkan dalam Tabel 2.

\section{TABel 2. Green Objectives dari Rantai Pasok Industri Sawit}

\begin{tabular}{ll}
\hline \multicolumn{1}{c}{ Green Objectives } & \multicolumn{1}{c}{ Stakeholder } \\
\hline $\begin{array}{l}\text { Pengelolan Kebun yang } \\
\text { ramah lingkungan } \\
\text { Minimasi waste }\end{array}$ & Kebun, Supplier TBS \\
& $\begin{array}{l}\text { Bagian pengolahan TBS } \\
\text { (PPKS) }\end{array}$ \\
\hline $\begin{array}{l}\text { Penyimpanan CPO yang } \\
\text { mampu menjaga tingkat } \\
\text { keasaman rendah (FFA }\end{array}$ & $\begin{array}{l}\text { Sales, Sub-bagian } \\
\text { pengolaan storage tank }\end{array}$ \\
$\begin{array}{ll}\text { Rendah) } \\
\text { Minimasi dan penanganan }\end{array}$ & $\begin{array}{l}\text { Kebun, bagian transportasi, } \\
\text { bagian pengolahan CPO, }\end{array}$ \\
& sales \\
\hline $\begin{array}{l}\text { Pengelolaan kebun dan } \\
\text { pabrik pengelolaan kelapa } \\
\text { sawit yang yang } \\
\text { tersertifikasi ISPO atau }\end{array}$ & $\begin{array}{l}\text { Kebun, PPKS (pengelolaan } \\
\text { RSPO }\end{array}$ \\
\hline $\begin{array}{l}\text { Minimasi penggunaan air } \\
\text { dan tidak mengganggu } \\
\text { kebutuhan air masyarakat }\end{array}$ & Kebun, PPKS \\
\hline Pengelolaan limbah & Kebun, Bagian \\
& Pengolahan TBS ( PPKS), \\
& sales \\
\hline
\end{tabular}




\begin{tabular}{ll}
\hline $\begin{array}{l}\text { Maksimasi penggunaan } \\
\text { energi baru terbarukan }\end{array}$ & Transportasi, PPKS, sales \\
$\begin{array}{l}\text { Kepuasan konsumen terkait } \\
\text { produk CPO dari aspek }\end{array}$ & Sales \\
lingkungan & \\
\hline
\end{tabular}

\section{Perancangan KPI GSCM Industri Sawit}

Natalia \& Asturio menyusun KPI untuk industri manufaktur dengan menurunkan green objectives yang telah disusun. Sama halnya dengan key performances indicator (KPI) GSCM dari industri sawit disusun dari menurunkan dari green objectives yang telah disusun pada tabel 2. KPI yang telah tersusun ditampilkan dalam Tabel 3.

TABEL 3. Key Performance Indicators (KPI) Industri Sawit

\begin{tabular}{|c|c|}
\hline Green Objectives & KPI \\
\hline \multirow{5}{*}{$\begin{array}{l}\text { Pengelolan Kebun } \\
\text { yang ramah } \\
\text { lingkungan }\end{array}$} & $\begin{array}{l}\text { Tidak ada lahan hutan lindung } \\
\text { yang digunakan sebagai lahan } \\
\text { perkebunan }\end{array}$ \\
\hline & $\begin{array}{l}\text { Persentase level kandungan racun } \\
\text { pestisida }\end{array}$ \\
\hline & $\begin{array}{l}\text { Pembuangan wadah pestisida yang } \\
\text { aman }\end{array}$ \\
\hline & Pencegahan kebakaran hutan \\
\hline & $\begin{array}{l}\text { Praktek irigasi yang mempu } \\
\text { meminimalisir erosi }\end{array}$ \\
\hline Minimasi waste & $\begin{array}{l}\text { Rendemen CPO } \\
\text { Kadar air pada CPO }\end{array}$ \\
\hline $\begin{array}{l}\text { Penyimpanan CPO } \\
\text { yang mampu } \\
\text { menjaga tingkat } \\
\text { keasaman rendah } \\
\text { (FFA Rendah) } \\
\end{array}$ & Kadar FFA CPO \\
\hline \multirow{4}{*}{$\begin{array}{l}\text { Minimasi dan } \\
\text { penanganan emisi } \\
\text { gas rumah kaca }\end{array}$} & Emisi gas rumah kaca \\
\hline & $\begin{array}{l}\text { Jumlah penggunaan bahan bakar } \\
\text { dalam pengiriman TBS }\end{array}$ \\
\hline & $\begin{array}{l}\text { Persen emisi dari POME ( Palm } \\
\text { Oil Mill Effluent ) }\end{array}$ \\
\hline & $\begin{array}{l}\text { Emisi dari pengiriman } \mathrm{CPO} \text { ke } \\
\text { konsumen }\end{array}$ \\
\hline $\begin{array}{l}\text { Pengelolaan kebun } \\
\text { dan pabrik } \\
\text { pengelolaan kelapa } \\
\text { sawit yang } \\
\text { tersertifikasi ISPO } \\
\text { atau RSPO } \\
\end{array}$ & $\begin{array}{l}\text { Persentase TBS dari kebun yang } \\
\text { tersertifikasi ISPO atau RSPO }\end{array}$ \\
\hline \multirow{2}{*}{$\begin{array}{l}\text { Minimasi } \\
\text { penggunaan air dan } \\
\text { tidak mengganggu } \\
\text { kebutuhan air }\end{array}$} & $\begin{array}{l}\text { Persen penggunaan air per ton TBS } \\
\text { di PPKS }\end{array}$ \\
\hline & $\begin{array}{l}\text { Penggunaan air di kebun tidak } \\
\text { mengganggu kebutuhan }\end{array}$ \\
\hline
\end{tabular}

\begin{tabular}{|c|c|}
\hline masyarakat & masyarakat \\
\hline \multirow{4}{*}{ Pengelolaan limbah } & BOD air limbah sesuai standar \\
\hline & COD air limbah sesuai standar \\
\hline & $\begin{array}{l}\text { Penyimpanan limbah B3 yang } \\
\text { aman }\end{array}$ \\
\hline & $\begin{array}{l}\text { Pemanfaatan limbah cair untuk } \\
\text { land aplikasi } \\
\text { Pembuangan limbah yang baik }\end{array}$ \\
\hline \multirow{2}{*}{$\begin{array}{l}\text { Maksimasi } \\
\text { penggunaan energi } \\
\text { baru terbarukan }\end{array}$} & $\begin{array}{l}\text { Penggunaan energi terbarukan } \\
\text { perton TBS }\end{array}$ \\
\hline & $\begin{array}{l}\text { Pemanfaatan limbah padat } \\
\text { (cangkang dan janjangan kosong) } \\
\text { sebagai ganti bahan bakar fosil }\end{array}$ \\
\hline $\begin{array}{l}\text { Kepuasan konsumen } \\
\text { terkait produk CPO } \\
\text { dari aspek } \\
\text { lingkungan } \\
\end{array}$ & $\begin{array}{l}\% \text { CPO tersertifikasi ISPO atau } \\
\text { RSPO }\end{array}$ \\
\hline
\end{tabular}

\section{Menyusun Hirarki Indikator GSCM Industri Sawit}

Penyusunan hirarki GSCM Industri sawit ini merupakan tahap awal dalam menggunakan metodek AHP (Analytical Hierarchy Process). AHP pertama kali diperkenalkan oleh Thomas L. Saaty di tahun 1971 dan menjadi metode yang sangat luas digunakan sebagai pengambilan keputusan dengan banyak kriteria. Pendekatan AHP juga digunakan oleh praktisi dan akademisi untuk menyelesaikan permasalahan bidang manajemen. AHP sebagai metode pemecahan masalah yang fleksibel dan sistematis dimana dapat merepresentasikan permasalahan yang kompleks (Saaty, 2008; Chan et al., 2006). Menurut Cheng et al. (2006) AHP memiliki beberapa manfaat. Pertama, AHP dapat digunakan untuk menurunkan permasalahan yang tidak terstruktur menjadi hirarki yang rasional untuk penyelesaian masalah. Kedua, AHP dapat menampilkan informasi dari ahli ataupun pengambil keputusan dari kelompok yang berbeda menggunkan perbandingan berpasangan. Ketiga, AHP dapat digunakan untuk menghitung bobot dari elemen yang berbeda. Keempat, AHP menggunakan pengukuran yang konsisten untuk memvalidasi nilai yang diberikan oleh ahli ataupun pengambil keputusan. Gambar 3 menunjukkan hirarki dari KPI GSCM industri sawit di Indonesia. 


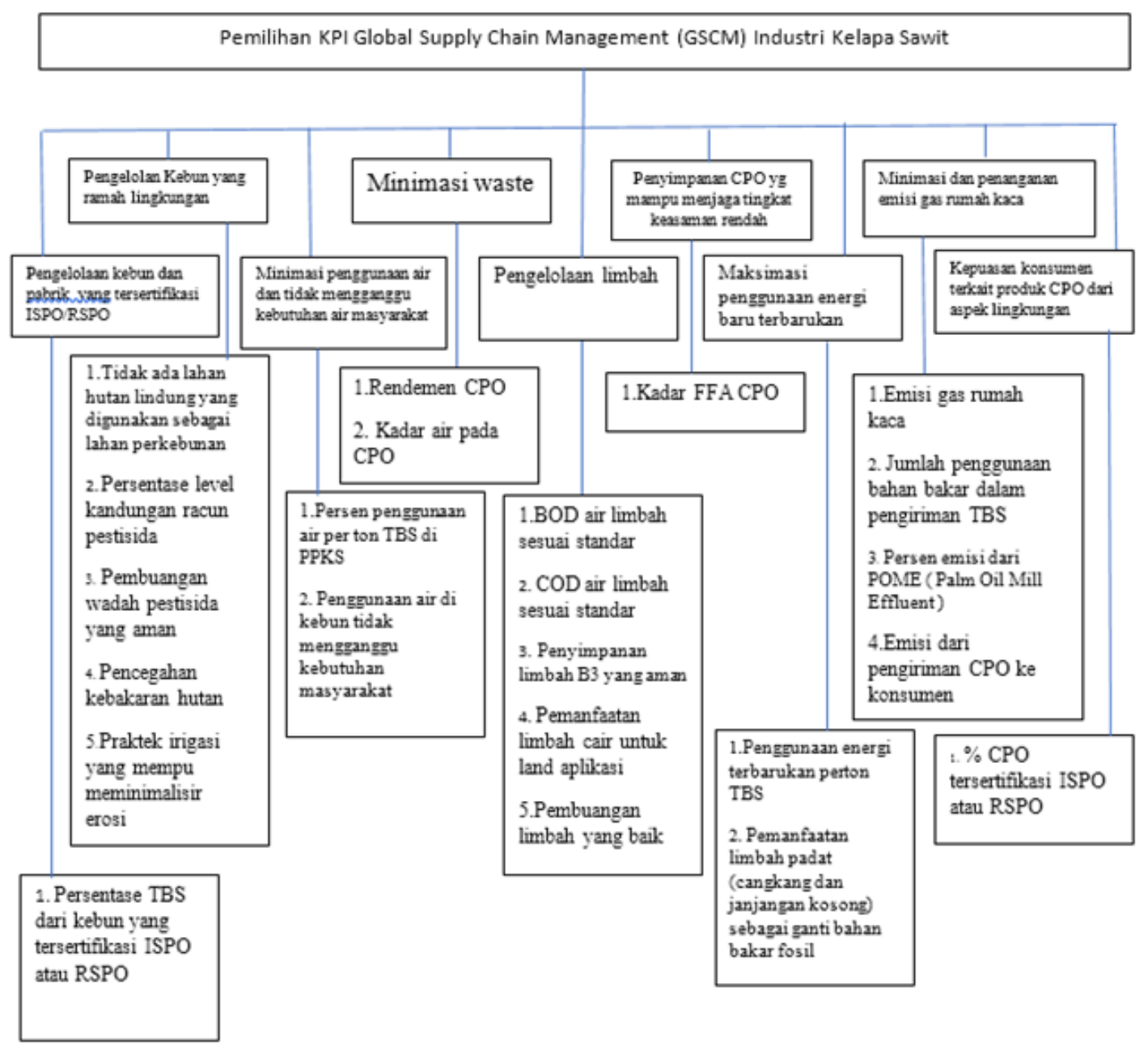

GAMBAR 3. Hirarki KPI GSCM Industri Sawit di Indonesia

\section{Pembobotan KPI}

Setelah hirarki terbentuk, bobot tingkat kepentingan kemudian diukur. Sebuah kuesioner perbandingan berpasangan antar indicator dari total 10 expert dalam industri kelapa sawit ditanyai preferensinya. Semua expert mengisi kuesioner secara cermat berdasarkan pengalamannya di industry kelapa sawit. Skala perbandingan yang digunakan antar KPI adalah 1 sampai 9 (1 = sama, $3=$ sedang, $5=$ kuat, $7=$ sangat kuat, $9=$ ekstrim). Consistency Ratio (CR) digunakan untuk mengecek konsistensi dari perbandingannya. Jika CR kurang dari 1 artinya perbandingan diterima. Berdasarkan perhitungan $\mathrm{CR}$, nilainya antara 0.01674 dan 0.09568 , yang artinya perbandingan berpasangannya konsisten karena berada pada range yang bisa diterima. Ini menunjukkan experts memberikan penilaian yang konsisten dalam pembobotan KPI green supply chain management industry sawit. Tabel KPI GSCM indsutri sawit di Indonesia dapat di lihat pada Tabel 4. 
TABEL 4. Bobot Key Performance Indicator GSCM Industri Sawit di Indonesia

\begin{tabular}{|c|c|c|c|c|}
\hline $\begin{array}{l}\text { Green } \\
\text { Objectives } \\
\text { (GO) }\end{array}$ & Bobot & & KPI & Bobot \\
\hline \multirow{5}{*}{$\begin{array}{c}\text { Pengelolan } \\
\text { Kebun yang } \\
\text { ramah } \\
\text { lingkungan }\end{array}$} & \multirow{5}{*}{0.093} & 1 & $\begin{array}{l}\text { Tidak ada } \\
\text { lahan hutan } \\
\text { lindung } \\
\text { yang } \\
\text { digunakan } \\
\text { sebagai } \\
\text { lahan } \\
\text { perkebunan }\end{array}$ & 0.020 \\
\hline & & 2 & $\begin{array}{l}\text { Persentase } \\
\text { level } \\
\text { kandungan } \\
\text { racun } \\
\text { pestisida }\end{array}$ & 0.020 \\
\hline & & 3 & $\begin{array}{l}\text { Pembuanga } \\
\mathrm{n} \text { wadah } \\
\text { pestisida } \\
\text { yang aman }\end{array}$ & 0.009 \\
\hline & & 4 & $\begin{array}{l}\text { Pencegahan } \\
\text { kebakaran } \\
\text { hutan }\end{array}$ & 0.022 \\
\hline & & 5 & $\begin{array}{l}\text { Praktek } \\
\text { irigasi yang } \\
\text { mampu } \\
\text { meminimali } \\
\text { sir erosi } \\
\end{array}$ & 0.021 \\
\hline \multirow{2}{*}{$\begin{array}{l}\text { Minimasi } \\
\text { waste }\end{array}$} & \multirow[t]{2}{*}{0.059} & 6 & $\begin{array}{l}\text { Rendemen } \\
\text { CPO }\end{array}$ & 0.050 \\
\hline & & 7 & $\begin{array}{l}\text { Kadar air } \\
\text { pada CPO }\end{array}$ & 0.009 \\
\hline $\begin{array}{c}\text { Penyimpana } \\
\text { n CPO yang } \\
\text { mampu } \\
\text { menjaga } \\
\text { tingkat } \\
\text { keasaman } \\
\text { rendah } \\
\text { (FFA } \\
\text { Rendah) } \\
\end{array}$ & 0.029 & 8 & $\begin{array}{l}\text { Kadar FFA } \\
\text { CPO }\end{array}$ & 0.029 \\
\hline \multirow{4}{*}{$\begin{array}{l}\text { Minimasi } \\
\text { dan } \\
\text { penanganan } \\
\text { emisi gas } \\
\text { rumah kaca }\end{array}$} & \multirow{4}{*}{0.159} & 9 & $\begin{array}{l}\text { Emisi gas } \\
\text { rumah kaca }\end{array}$ & 0.066 \\
\hline & & 10 & $\begin{array}{l}\text { Jumlah } \\
\text { penggunaan } \\
\text { bahan bakar } \\
\text { dalam } \\
\text { pengiriman } \\
\text { TBS }\end{array}$ & 0.043 \\
\hline & & 11 & $\begin{array}{l}\text { Persen emisi } \\
\text { dari POME } \\
\text { ( Palm Oil } \\
\text { Mill } \\
\text { Effluent ) }\end{array}$ & 0.032 \\
\hline & & 12 & $\begin{array}{l}\text { Emisi dari } \\
\text { pengiriman } \\
\text { CPO ke } \\
\text { konsumen }\end{array}$ & 0.018 \\
\hline $\begin{array}{l}\text { Pengelolaan } \\
\text { kebun dan } \\
\text { pabrik } \\
\text { pengelolaan } \\
\text { kelapa sawit } \\
\text { yang }\end{array}$ & 0.297 & 13 & $\begin{array}{l}\text { Persentase } \\
\text { TBS dari } \\
\text { kebun yang } \\
\text { tersertifikasi } \\
\text { ISPO atau } \\
\text { RSPO }\end{array}$ & 0.297 \\
\hline
\end{tabular}

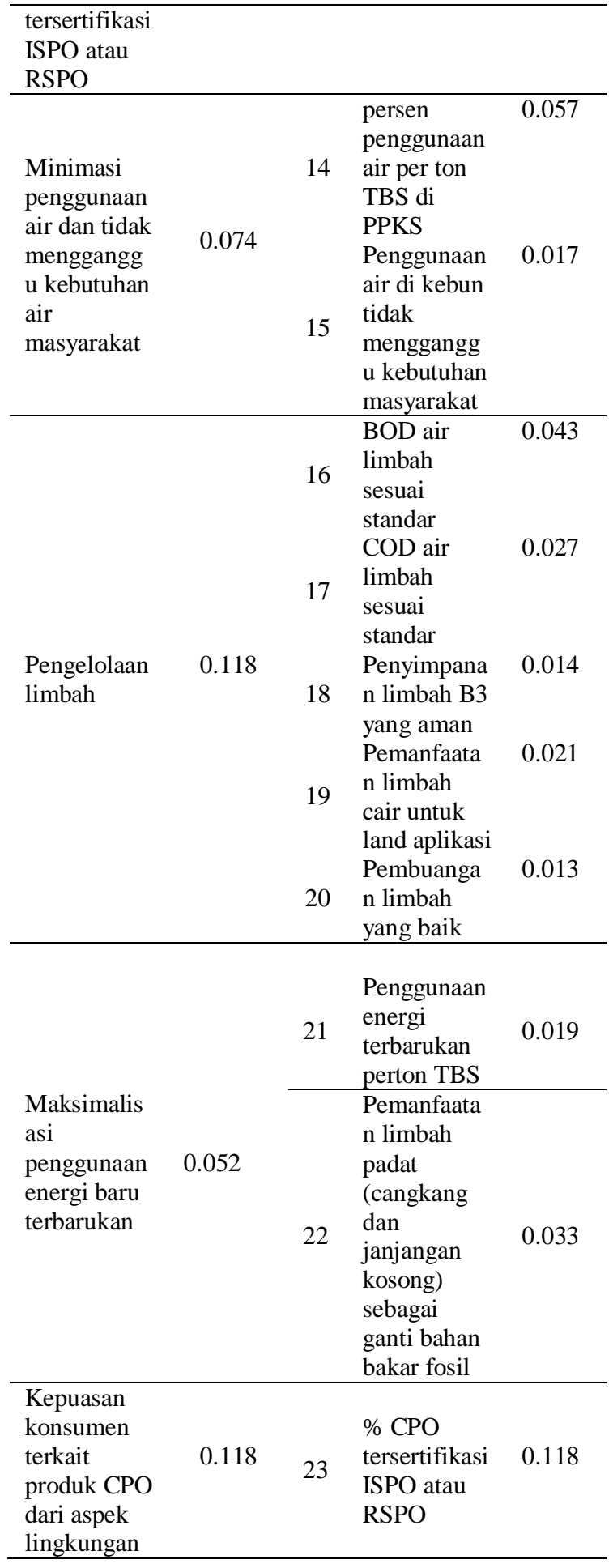

\section{KESIMPULAN}

Green objectives dengan bobot tertinggi pada pengelolaan kebun dan pabrik kelapa sawit yang tersertifikasi ISPO atau RSP sebesar 29,7\%, Minimalisasi dan penanganan emisi gas rumah kaca dan pengelolaan limbah dengan bobot sebesar $15,9 \%$ dan $11,8 \%$. Sementara KPI dengan bobot tertinggi yaitu ada pada persentase TBS dari kebun yang 
tersertifikasi ISPO atau RSPO sbesar 29,7\%, CPO tersertifikasi ISPO atau RSPO sebesar $11,8 \%$ dan Emisi gas rumah kaca sebesar 6,6 $\%$.

\section{DAFTAR PUSTAKA}

Chan, F.T., Chan, H.K., Lau, H.C. and Ip, R.W., 2006. An AHP approach in benchmarking logistics performance of the postal industry. Benchmarking: An International Journal

Cheng, E.W., Li, H. and Ho, D.C., 2002. Analytic hierarchy process (AHP). Measuring Business Excellence

Delipinar G.E. \& Kocaoglu B., 2016. Using SCOR Model to Gain Competitive Advantage: A Literature Review. Procedia-Social and Behavioral Sciences 229, 398-406

Fortuna, I.F., Suamtri, Y. and Yuniarti, R., 2014. Perancangan Sistem Pengukuran Kinerja Aktivitas Green Supply Chain Management (Gscm) Studi Kasus: KUD Batu. Jurnal Rekayasa dan Manajemen Sistem Industri, 2(3), pp.p551-562

Kusrini, E. and Primadasa, R., 2018. Design of key performance indicators (KPI) for sustainable supply chain management (SSCM) palm oil industry in Indonesia. In MATEC web of conferences (Vol. 159, p. 02068). EDP Sciences

Min, H. and Zhou, G., 2002. Supply chain modeling: past, present and future. Computers \& industrial engineering, 43(1-2), pp.231-249

Natalia, C. and Astuario, R., 2015. Penerapan model green SCOR untuk pengukuran kinerja green supply chain. Jurnal Metris, 16(2), pp.97-106

Ntabe, E.N., LeBel, L., Munson, A.D. and Santa-Eulalia, L.A., 2015. A systematic literature review of the supply chain operations reference (SCOR) model application with special attention to environmental issues. International Journal of Production Economics, 169, pp.310-332

Olugu, E.U., Wong, K.Y., \& Shaharoun, A.M., 2010. A Comprehensive Approach in Assessing the Performance of an Automobile closed loop Supply Chain. Sustainability, 2(4), 871-879
Saaty, T.L., 2007. The analytic hierarchy and analytic network measurement processes: applications to decisions under risk. European journal of pure and applied mathematics, 1(1), pp.122196.

Torres, B., Nones, S., Morques, S., \& Evgenio, R., 2004. A Theoretical Approach for Green Supply Chain Management. Federal University DO RIO GRANDE, Industrial Engineering Program, NATAL-BRAZIL

Zhu, Q. and Cote, R.P., 2004. Integrating green supply chain management into an embryonic eco-industrial development: a case study of the Guitang Group. Journal of Cleaner Production, 12 (810), pp.1025-1035.

https://economy.okezone.com/read/2018/03/15/3 20/1873034/sawit-penting-bagiperekonomian-ri-ini-alasannya?page $=2$, diakses 20 Maret 2018.

https://gapki.id/news/1860/industri-minyaksawit-merupakan-industri-strategisnasional, diakses 20 Maret 2018.

https://sawitindonesia.com/rubrikasimajalah/artikel/kondisi-kekiniantantangan-dan-realitas-pembangunanperkebunan-kelapa-sawit-berkelanjutaneko-zulkiflispm-sc/, diakses 20 Maret 2018. 